Article

\title{
Investigation of Marine Wind Veer Characteristics Using Wind Lidar Measurements
}

\author{
Zhenru Shu ${ }^{1}$, Qiusheng $\mathrm{Li}^{2,3, *}$, Yuncheng $\mathrm{He}^{4}$ and Pak Wai Chan ${ }^{5}$ \\ 1 Department of Civil Engineering, University of Birmingham, Edgbaston B15 2TT, UK; z.shu@bham.ac.uk \\ 2 Department of Architecture and Civil Engineering, City University of Hong Kong, Hong Kong 999077, China \\ 3 Architecture and Civil Engineering Research Centre, Shenzhen Research Institute of City University of \\ Hong Kong, Shenzhen 518057, China \\ 4 Joint Research Centre for Disaster Prevention and Control of Engineering Structures, Guangzhou University, \\ Guangzhou 510006, China; yuncheng@gzhu.edu.cn \\ 5 Hong Kong Observatory, Kowloon, Hong Kong 999077, China; pwchan@hko.gov.hk \\ * Correspondence: bcqsli@cityu.edu.hk
}

Received: 9 September 2020; Accepted: 28 October 2020; Published: 31 October 2020

check for updates

\begin{abstract}
A proper understanding of marine wind characteristics is of essential importance across a wide range of engineering applications. While the offshore wind speed and turbulence characteristics have been examined extensively, the knowledge of wind veer (i.e., turning of wind with height) is much less understood and discussed. This paper presents an investigation of marine wind field with particular emphasis on wind veer characteristics. Extensive observations from a light detection and ranging (Lidar) system at an offshore platform in Hong Kong were examined to characterize the wind veer profiles up to a height of $180 \mathrm{~m}$. The results underscored the occurrence of marine wind veer, with a well-defined two-fold vertical structure. The observed maximum wind veer angle exhibits a reverse correlation with mean wind speed, which decreases from $2.47^{\circ}$ to $0.59^{\circ}$ for open-sea terrain, and from $7.45^{\circ}$ to $1.92^{\circ}$ for hilly terrain. In addition, seasonal variability of wind veer is apparent, which is most pronounced during spring and winter due to the frequent occurrence of the low-level jet. The dependence of wind veer on atmospheric stability is evident, particularly during winter and spring. In general, neutral stratification reveals larger values of wind veer angle as compared to those in stable and unstable stratification conditions.
\end{abstract}

Keywords: marine wind characteristic; wind veer; Lidar observation; terrain effect; seasonal variability; atmospheric stability

\section{Introduction}

Energy harvesting from renewable energy sources is one of the major strategies to effectively reduce carbon footprints and accelerate sustainable development. The share of renewable energy sources of global electricity generation reached 26.4\% in 2018 [1,2]. Renewable energy contains a mix of various technologies, such as wind energy, solar energy, tidal power, etc., which are naturally replenished on different timescales. In particular, wind energy is one of the mainstream renewable energy sources, which has been seen to develop at a remarkable pace across the world due to the high availability of resources and the maturity of the technology in terms of cost efficiency [3]. In 2019, the global new wind power installations surpassed $60 \mathrm{GW}$, a growth of $19 \%$ compared to 2018, and the total installed capacity rose to $650 \mathrm{GW}$ [4]. It is worth mentioning that, while onshore wind power is still dominating the market, accounting for more than $95 \%$ of the total installations, offshore wind power has become increasing prevalent, especially in China, the United Kingdom and Germany [4].

Due to the differences in the respective installation environments, offshore wind power tends to exhibit a number of advantages compared to traditional onshore wind power $[3,5]$ : 
- wind resources in the offshore areas are generally of better quality, with greater wind speed and less turbulence, which could lead to less fatigue load and a longer lifetime of wind turbine generators; - the more extensive free space in offshore areas allows for large-scale wind farms to be installed. In the meantime, negative environmental effects, such as noise emission and visual impact, can be largely minimized.

As an essential input for mapping and planning offshore wind power, accurate information on marine wind characteristics are met with increasing attention, which could provide important implications in different aspects of offshore wind power development [6,7], ranging from the assessment of wind power potential and the identification of wind turbine design parameters to the optimization of the overall layout of wind farms. The marine atmospheric boundary layer (MABL) refers to the part of the atmosphere that has direct contact with, and therefore is inevitably influenced by, the ocean. It is where the ocean and atmosphere exchange large amounts of heat, moisture and momentum, primarily via turbulent transport [8]. Svensson et al. [9] highlighted that the wind and turbulence characteristics in offshore areas are controlled by different forcing as compared to onshore meteorology. Specifically, the wind conditions in onshore sites are mainly modulated by local surface roughness, topography and the diurnal variation of surface forcing, whereas the winds in offshore sites are primarily governed to a larger degree by the synoptic weather and the conditions on the upwind coast. Given the notable increase in coastal and marine activities, extensive studies have been carried out with respective emphasis on a broad range of marine wind characteristics, such as vertical wind speed profile [10-16], wind speed distribution [17-19], seasonal and diurnal variability [20-22] and surface roughness [23-25], as well as turbulence intensity [26]. However, the knowledge associated with the change of wind direction with height, i.e., wind veer, is much less understood and discussed.

Numerous observational studies have evidenced that winds within the atmospheric boundary layer always veer as a function of height $[27,28]$, which, in consequence, results in a more realistic representation of boundary layer wind with a spiral-shaped structure. The occurrence of wind veer may be driven by different mechanisms [29], and is governed by the balance of forces governing air motion: the pressure gradient force, the Coriolis force and the friction force due to Earth surface roughness $[28,30,31]$. Under idealized conditions, Ekman theory suggested a wind veer of $45^{\circ}$ in the atmospheric boundary layer, which in reality may decrease to $15-40^{\circ}$ depending on atmospheric stability [29]. Mendenhall [27] concluded that observed wind veer is decreased when cold advection and thermal instability (i.e., steep lapse rates) prevail. Accordingly, an actual veer of $10^{\circ}$ over the ocean and $20^{\circ}$ over land can be predicted with corrections of lapse rate and pressure gradient rotation. Crawford and Hudson [32] and Peña et al. [33] found evident diurnal oscillation of wind veer, in which the maximum veer generally occurs at night, whereas the minimum is more likely to be observed at midday. Brown et al. [29] stated that the wind veer across the boundary layer depends primarily on thermal advection, but has little dependence on surface friction. Peña et al. [31,33,34] showed that the characteristics of wind veer may change as a function of atmospheric stability and forcing conditions. Their results suggested a typical wind veer angle of $25^{\circ}$ for neutral conditions and $45^{\circ}$ for stable conditions. He et al. [35] revealed significant wind veer, with an angle of approximately $20^{\circ}$ to $40^{\circ}$ between surface level and a height of $1000 \mathrm{~m}$, during the passage of typhoons. Liu et al. [36] also identified the occurrence of wind veer within the first $1000 \mathrm{~m}$ above the ground, the angle of which ranges from $5^{\circ}$ to $40^{\circ}$. Shu et al. [37] examined the dependence of the wind veer profile on upstream terrain conditions and mean wind speed. Lindvall and Svensson [38] reported that there is clear latitudinal dependence of wind veer, with angles increasing with latitude. Moreover, seasonal and diurnal cycles are also apparent, which is mostly related to the variations in thermal stratification.

The understanding of wind veer in the atmospheric boundary layer plays an essential role across various engineering applications, such as wind load on high-rise buildings $[28,30,39]$ pedestrian-level wind environments [40-42], yacht aerodynamics [43,44], the modeling of microscale and mesoscale atmospheric process [12], and, in particular, the performance of wind turbine and wind power output. Brugger et al. [45] found that a skewed and tilted wake structure can be observed when wind veer 
occurs, which is consistent with those predicted by simulation and wind tunnel tests. Churchfield and Sirnivas [46] also observed that the wake is noticeably skewed in the veered inflow condition as it moves downstream, which, however, is not a simple passive tracer-like process. Englberger and Lundquist [47] showed that the shape and magnitude of veer wind profile in the wake depend closely on the wind veer conditions in the inflow. Choukulkar et al. [48] highlighted that the wind veer (i.e., wind direction shear) exhibits significant impact on the wind power availability in addition to wind speed shear, which generally leads to a decline in power-producing capacity. Similar conclusions were also obtained by Bardal et al. [49], who found a reduced power output in the whole partial load regime under high veer conditions. In contrast, Eriksson et al. [50] examined the effect of wind veer and the Coriolis force on an idealized farm-to-farm interaction case, in which the estimated power production was found to increase with the inclusion of the wind veer effect. Murphy et al. [51] concluded that the influence of wind veer on turbine power production is strongly tied with wind speed, in which a large wind veer angle generally results in power gains at a wind speed exceeding $10 \mathrm{~m} / \mathrm{s}$. Below this threshold value, the impact of wind veer appears to be somewhat negligible.

Hong Kong is a developed city that depends heavily on sustainable energy supply. The local authorities and energy companies are actively exploring new ways to diversify the energy supply portfolio with a view to achieve a less carbon-intensive and more sustainable energy system, among which, notably, offshore wind power has been established as a promising and cost-competitive renewable energy source. In such a context, several precedent studies have been undertaken to examine the viability of offshore wind power development in Hong Kong [52-55]. In particular, the authors present a series of studies with relevance to the assessment of offshore wind characteristics for wind energy application $[5,18,56]$.

Nevertheless, it is worth mentioning that the aforementioned studies were primarily focused on the statistical analysis of wind speed and wind energy potential, whereas the information of wind veer at offshore sites, particularly in Hong Kong, has rarely been discussed and documented. Current design codes and standards for wind turbines or other marine-based structures have not taken into account the wind veer, which is possibly due to the lack of systematic wind veer assessment. On the other hand, given the complexity of forcing agents governing marine wind veer, its characteristics are likely to be site dependent. On this account, the current study is a continuation and extension of our previous study, with particular emphasis on marine wind veer characteristics. Extensive wind observations from a light detection and ranging (Lidar) system equipped at an offshore platform in Hong Kong are included and analyzed. The rest of this paper is organized as follows: Section 2 presents detailed information related to data collection and processing. Analyzed results and a discussion are documented in Section 3, and the major conclusions are summarized in Section 4.

\section{Data Collection and Processing}

\subsection{Site Description and Measurement Instrumentation}

The marine wind observation platform is located in the southern waters of Lamma Island (see Figure 1), with a nearest distance of approximately $3.5 \mathrm{~km}$. Cheung Chau Island and Lantau Island are located off the northwest of the platform, with a distance of, respectively, $9 \mathrm{~km}$ and $15 \mathrm{~km}$. The platform is exposed to a fairly open-sea terrain within the range of $60-240^{\circ}$ [24]. Wind speed and wind direction data are recorded by a comprehensive measurement system, consisting of a meteorological mast and a wind Lidar system (see Figure 1). In this study, a marine wind observation campaign was undertaken during the period from March 2012 to November 2015.

The wind mast is of a lattice structure design with a total height of approximately $22 \mathrm{~m}$, where a pair of side-mounted A100L2 cup anemometers (manufactured by Vector Instrument) are positioned at $21.3 \mathrm{~m}$ above mean sea level (MSL), orientating, respectively, towards the northwest (denoted as NW anemometer, hereafter) and the southeast (SE anemometer, hereafter). Wind direction data are recorded by a wind vane (manufactured by Vector Instrument) located $18.6 \mathrm{~m}$ above MSL, orientating 
towards the southeast. In order to eliminate the potential interference effect from the physical structure of the mast, the paired anemometers and the wind vane are mounted on horizontal cylindrical booms with a distance of $2.3 \mathrm{~m}$ to the center of the mast. The cup anemometer and wind vane were configured to record instantaneous data at a sampling rate of $1 \mathrm{~Hz}$, which were further averaged and output at a time interval of 10 min using a CR3000 micro-logger system (manufactured by Campbell Scientific). The wind mast records contained the $10 \mathrm{~min}$ mean and standard deviation of wind speed and wind direction.

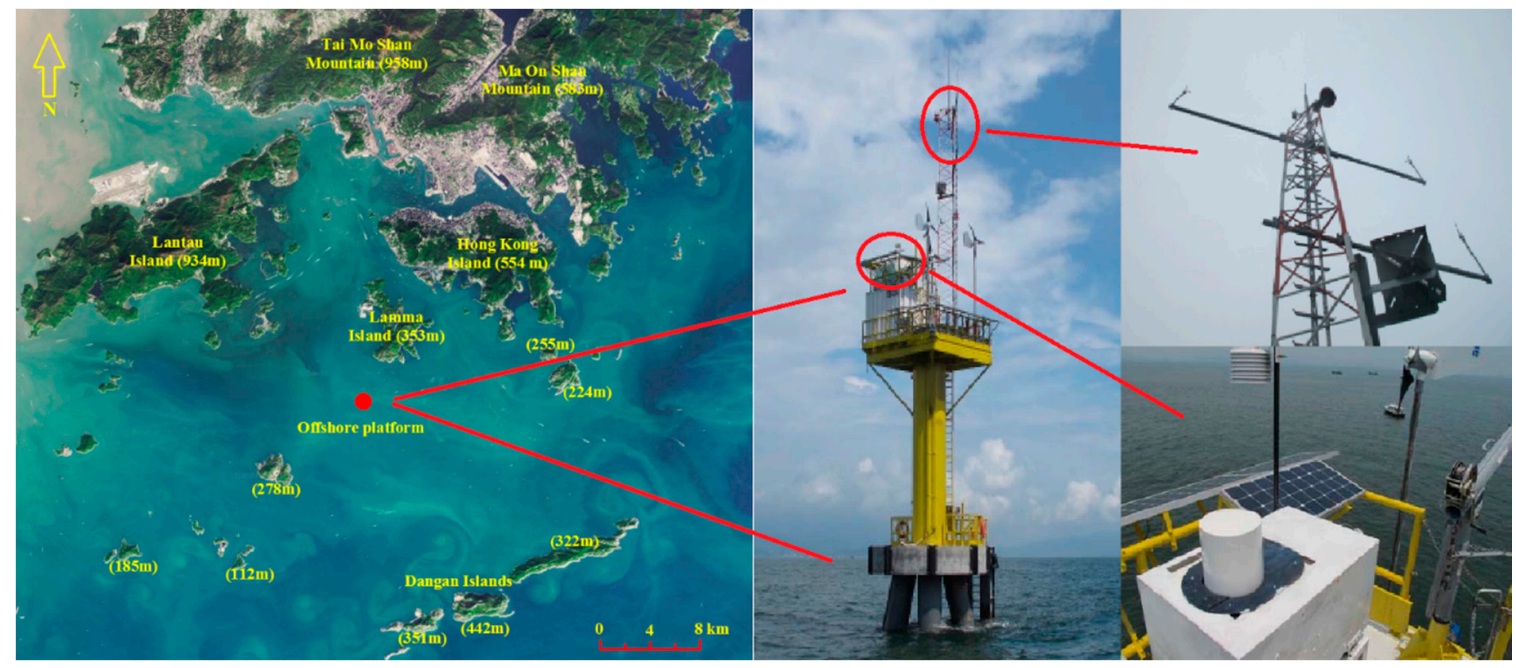

Figure 1. Location of measurement site (highlighted in solid red circle) and wind measurement system (upper: met mast; bottom: wind Lidar).

It is noteworthy that, although a traditional wind mast has been predominantly used for measuring and collecting wind data, its measurement height is often limited up to $50 \mathrm{~m}$ to $100 \mathrm{~m}$ due to structural and cost constraints, which is unsuitable for the proper observation of wind characteristics for utility-scale turbines with typical hub heights of $100 \mathrm{~m}$ to $130 \mathrm{~m}$ and rotor diameters of $150 \mathrm{~m}$ to 200 m [7,57]. Remote sensing technologies, in particular Doppler Lidar, are becoming increasingly popular in the wind energy community because of their ability to measure wind data over larger regions and higher altitudes [9]. In addition, Doppler wind Lidar reveals more flexibility in terms of transportation and installation, which is particularly important for offshore sites, given that the installation of a wind mast with either a fixed or floating platform can be prohibitively costly [7]. Given its practical usefulness, Doppler wind Lidar has been widely adopted for the accurate monitoring and collection of wind data [10-14,18,58-61].

The wind Lidar system equipped at the platform is a 2nd generation Galion G250 Lidar Unit (distributed by SgurrEnergy), with a standard measurement range of up to $250 \mathrm{~m}$. The wind speed measurement range is about $0-70 \mathrm{~m} / \mathrm{s}$, with an accuracy of $\pm 0.15 \mathrm{~m} / \mathrm{s}$. The Lidar system is fixed on the southwest corner of the platform, with a center-to-center distance of $2.3 \mathrm{~m}$ to the mast. Essentially, the Galion Lidar is a pulsed laser device, which provides wind speed and direction measurements at multiple programmable heights in a fully remote manner. The principle of wind Lidar measurements is that the Lidar system omits laser pulses into the atmosphere, which are reflected by the existing aerosols. The along beam velocity can be calculated from the frequency shift using the Doppler equation $[7,62]$. Throughout the measurement campaign, the wind Lidar was configured to operate in velocity azimuth display (VAD) mode, in which the azimuth angle is varied over a circle with the elevation angle fixed. The angular speed was about $30^{\circ} / \mathrm{s}$. Data filtering was applied to the original high-resolution Lidar data by means of wind field reconstruction and a carrier-to-noise (CNR) filter. Likewise to the wind mast data, the Lidar system was configured to output the mean and standard deviation of horizontal wind speed and mean horizontal wind direction at every $10 \mathrm{~min}$, the record time of which was well aligned with the mast data. In addition to the data filtering, rigorous data quality control (QC) was 
also performed to enhance the validity of the Lidar measurements. For example, the Lidar system has a built-in data quality flag indicating the amount of data used to compute the $10 \mathrm{~min}$ statistical values. The maximum value of the quality flag is 17 . In this study, a threshold quality flag of 12 is used to identify Lidar measurements with reasonable reliability. It is of note that, unlike other wind Lidar observation studies where the increment of measurement height is often a constant, the measurement height in this study is programmed in a non-uniform manner. The measurement height in the lower region $(21.3 \mathrm{~m}$ to $44.1 \mathrm{~m}$ ) increases at a vertical increment of $2.5 \mathrm{~m}$, while that in the upper region (44.1 $\mathrm{m}$ to $178.3 \mathrm{~m}$ ) increases at an interval of $20 \mathrm{~m}$.

\subsection{Fidelity of Wind Mast and Lidar Measurements}

Prior to the analysis, it is important to examine the fidelity of the data involved. Given that the reliability of wind Lidar measurements is often validated using the nearby wind mast data [57], Figure 2 demonstrates the comparison of the $10 \mathrm{~min}$ mean and standard deviation of wind speed recorded by the paired cup anemometers (i.e., NW and SE), in which the fidelity of wind mast data can be represented by a ratio close to the standard value of 1 . It is shown that the consequent ratio in regard to both the mean and standard deviation of the wind speed deviates remarkably from the standard value when the wind approaches from the direction of $135^{\circ}$ and $300^{\circ}$, implying that the recorded wind data are likely to be obstructed by the physical mast structure within these direction ranges. Hence, in light of the methodology by Svensson et al. [9], the distorted wind mast data, i.e., those located within the shaded area in Figure 2, are not included in the following comparison analysis.
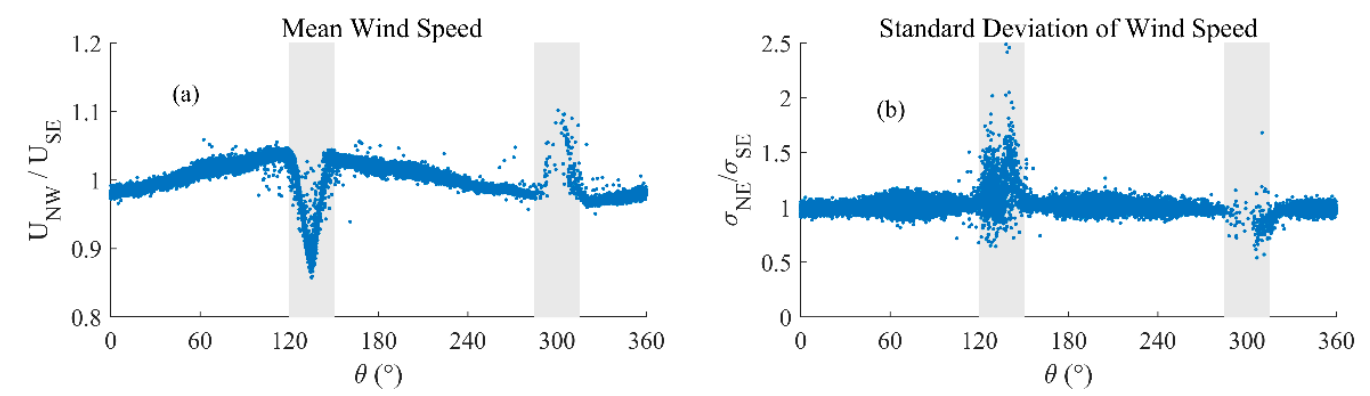

Figure 2. Comparison of wind speed characteristics between the paired cup anemometers installed on the mast. Wind direction ranges affected by mast interference effect are shaded. (a) 10-min mean wind speed (b) standard deviation of wind speed

Once the reliable wind mast data are extracted, the fidelity of the wind Lidar measurement can be routinely examined by comparing the synchronized mast and Lidar data at equivalent heights (i.e., $21.3 \mathrm{~m}$ ), as shown in Figure 3. The comparisons of mean wind speed and wind direction are overall above the satisfactory level, with correlation coefficients above 0.95 and regression slopes above 0.93. The root mean square error (RMSE) for mean wind speed is $0.80 \mathrm{~m} / \mathrm{s}$, and that for mean wind direction is $7.59^{\circ}$. However, the standard deviations of wind speed measured by Lidar are found to be attenuated as compared to their counterparts, resulting in a correlation coefficient of 0.73 and a regression slope of 0.76 . This is mainly attributed to the fact that the conical scanning feature of Lidar does not effectively resolve the turbulence with a length scale smaller than the probe length, which can result in a 20\% reduction of the standard deviation measurement [63]. Similar results are also found by Peña et al. [11] and Shu et al. [18]. Since this study is focused primarily on the wind direction data, the attenuation of the standard deviation of the wind speed in Lidar data is neglected. 

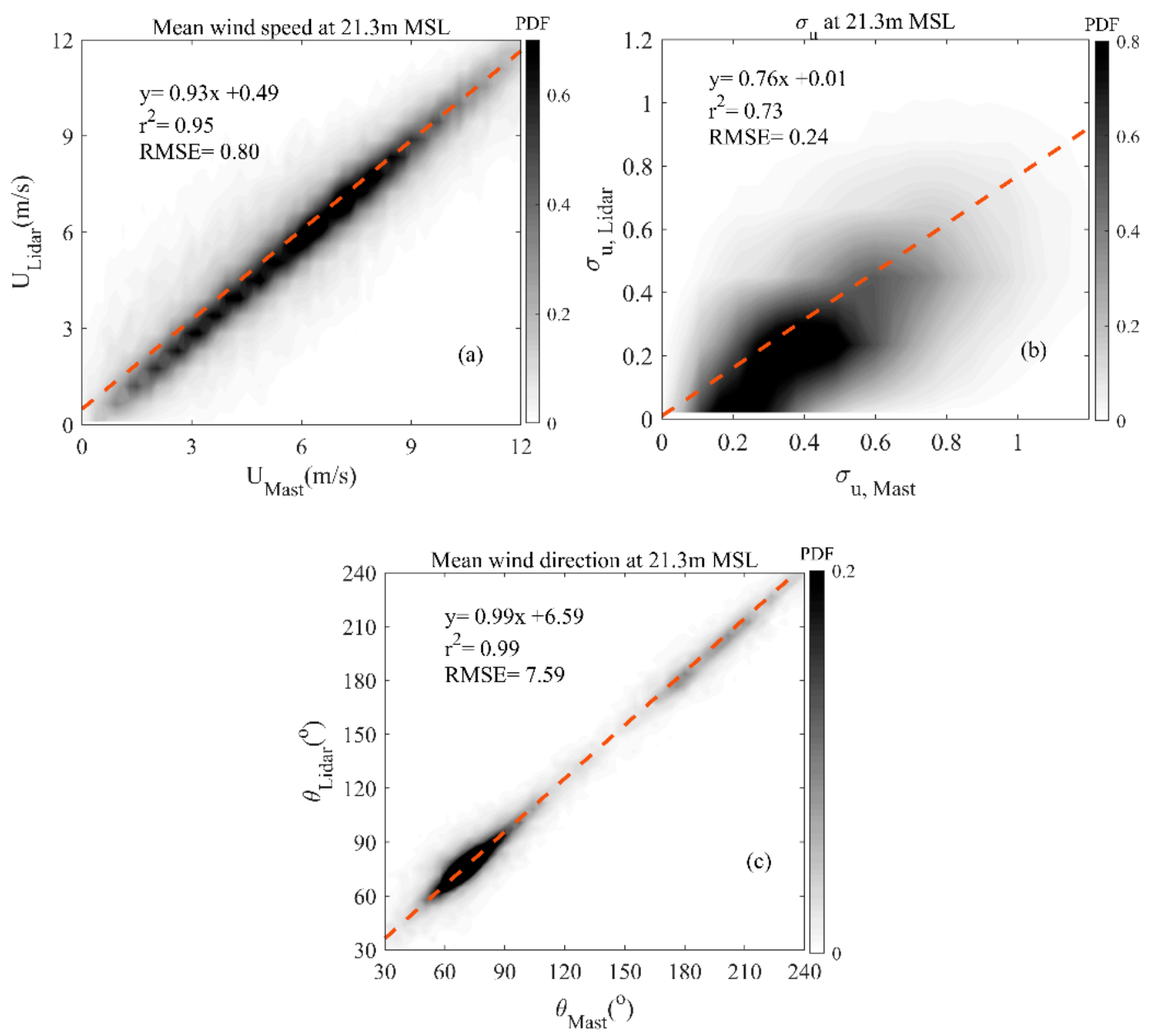

Figure 3. Comparison of mast and wind Lidar measurements at $21.3 \mathrm{~m}$ above mean sea level (MSL) (each pixel represents the probability density function (PDF) normalized by the maximum PDF value; red dotted line represents the best linear fit). (a) mean wind speed (b) standard deviation of wind speed (c) mean wind direction.

\subsection{Definition of Wind Veer Angle and Composite Analysis}

In the meteorological community, the wind veer is standardly defined as when the wind turns clockwise as a function of height, while the wind back indicates a counter-clockwise turning of the wind. Fundamentally, wind veer is mostly associated with warm air advection and dynamic lifting, while wind back, in contrast, is related to cold air advection and dynamic sinking. In this study, the wind veer angle is defined as the deficit of wind direction measurements between the lowest observation level and those at higher altitudes. It should be mentioned that, in order to minimize the uncertainties associated with the variability of mesoscale, convective and small turbulent scales, the original $10 \mathrm{~min}$ data are further averaged to provide the corresponding $1 \mathrm{~h}$ means.

Given the availability of wind data involved in the current study, analyses of wind speed and wind veer profiles are conducted in a composite sense. Composite analysis is a powerful technique to identify the most distinctive characteristics of a meteorological or climatological phenomenon that is difficult to observe in totality. Composite analysis usually involves collecting large numbers of cases of a given meteorological phenomenon, and these cases are composited into a collection. In this case, the composite mean and some other statistical measures (e.g., standard deviation and statistical significance) can be estimated, which would provide a definitive picture of how such a meteorological phenomenon is influenced by the factors used in the composite stratification. Composite analysis has been extensively employed in previous studies, e.g., [64-73]. 


\section{Results and Discussion}

Figure 4 illustrates the wind rose plots based on hourly wind data at different heights, which show a reasonable agreement. The dominant wind direction sectors are $\mathrm{E}$ and ENE. In addition, the wind speed is shown to slightly increase with height, reflected by a larger proportion of high wind speed at elevated heights.
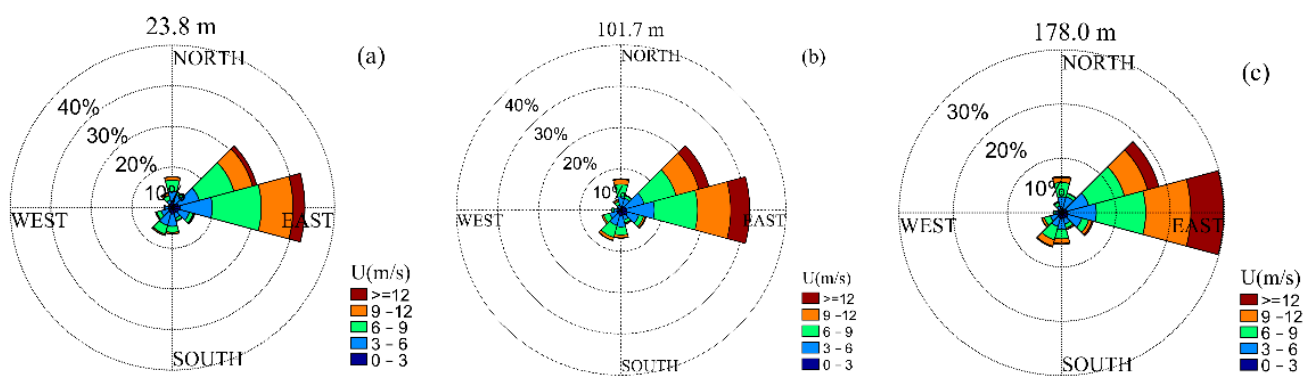

Figure 4. Wind rose plots based on wind Lidar measurements at different heights: (a) $23.8 \mathrm{~m}$, (b) $101.7 \mathrm{~m}$ and (c) $178 \mathrm{~m}$.

It has been well recognized that wind Lidar observations at this offshore platform can be heavily affected by the change in inflow direction due to the variation of upstream terrain [24]. Accordingly, the wind speed profiles in this study are divided into two main groups based on the mean boundary layer wind direction (see Figure 5): those from $60^{\circ}$ to $240^{\circ}$ are representative of a homogeneous open-sea terrain, while those from $0^{\circ}$ to $50^{\circ}$ and $290^{\circ}$ to $360^{\circ}$ are representative of a hilly terrain. As can be seen, the mean wind speed profiles under an open-sea terrain typically exhibit a monotonic-type increase with height, which coincides well with the general characteristics of atmospheric boundary layer flow. The mean wind speed up to a height of $120 \mathrm{~m}$ can be satisfactorily approximated by the logarithmic law model, resulting in a surface roughness length $(\mathrm{z} 0)$ ranging from $0.951 \mathrm{~mm}$ to $0.983 \mathrm{~mm}$. In contrast, the wind speed profiles associated with a hilly terrain appear to be more irregular in shape, which consistently exhibit a local maximum at a height of about $80 \mathrm{~m}$. This can potentially be caused by the presence of pronounced mountains in the corresponding direction, which is likely to disturb the wind flow. The performance of the logarithmic law fit of mean wind speed is not as good as that of the open-sea terrain. Moreover, the consequent surface roughness length lies in the range from $0.992 \mathrm{~mm}$ to $1.000 \mathrm{~mm}$, which is slightly larger that of the open-sea terrain.
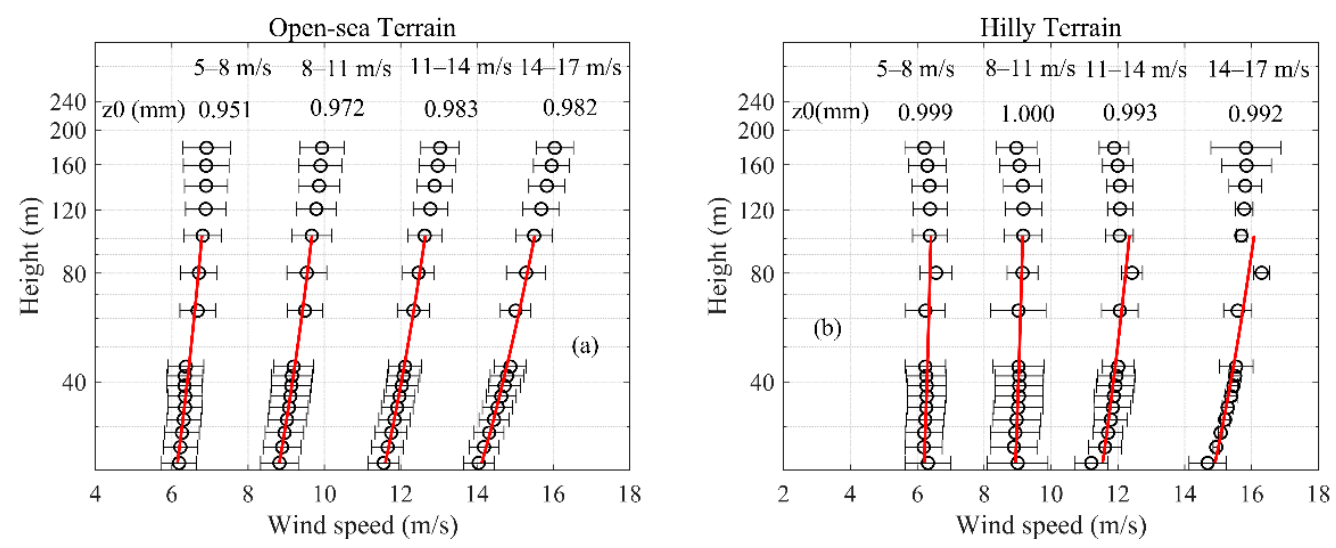

Figure 5. Composite vertical profiles of mean wind speed under different upstream terrain conditions. The circle represents the composited mean wind speed, and the error bar represents the standard deviation. The red solid line represents log-law fit of mean wind speed up to $120 \mathrm{~m}$. (a) for open-sea terrain, i.e., $60^{\circ}$ to $240^{\circ}$ (b) for hilly terrain, i.e., $0^{\circ}$ to $50^{\circ}$ and $290^{\circ}$ to $360^{\circ}$. 
Likewise, the vertical distribution of wind veer angle associated with different upstream terrain conditions is found to be somewhat different, as shown in Figure 6. The wind veer profiles for both open-sea and hilly terrain exhibit a well-defined two-fold vertical structure. For open-sea terrain conditions, the wind veer angle is found to slightly decrease and possess negative values in the lower observation region, indicating the possible occurrence of wind back. At heights above $60 \mathrm{~m}$, the value of the wind veer angle tends to increase monotonically with increasing height, reaching a maximum wind veer angle at about $180 \mathrm{~m}$ (i.e., the highest observation height in this study). It is clear that both the maximum wind veer angle and wind back angle (i.e., negative wind veer angle) are speed dependent. To illustrate, the maximum negative wind veer angle is found at a mean wind speed of $14-17 \mathrm{~m} / \mathrm{s}$, with a value of $-0.58^{\circ}$, and the maximum wind veer angle indicates a reverse relationship with mean wind speed, the value of which decreasing from $2.47^{\circ}$ to $0.59^{\circ}$ as the mean wind speed increases. In contrast, the wind veer profiles associated with the hilly terrain condition remain more or less unchanged up to a height of $45 \mathrm{~m}$. With a further increase in height, the wind veer angle also exhibits a steady increase. The maximum wind veer angle decreases from $7.45^{\circ}$ to $1.92^{\circ}$ as the mean wind speed increases. This is potentially caused by the change in atmospheric stability as mean wind speed changes. Overall, it is found that the wind veer angles for the hilly terrain condition are significantly larger than those for the open-sea terrain. In order to gain a more representative understanding of wind veer characteristics at offshore sites, only the data associated with the open-sea terrain are included in the following analysis, unless otherwise specified.
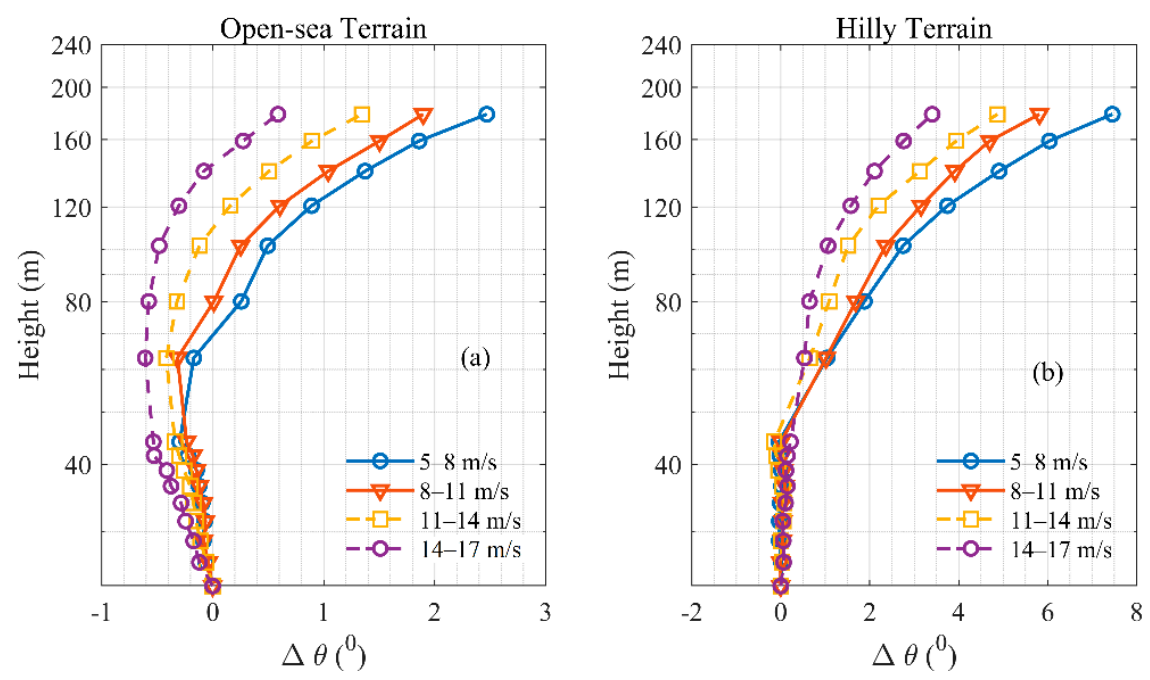

Figure 6. Composite wind veer profiles associated with different upstream terrains. (a) for open-sea terrain, i.e., $60^{\circ}$ to $240^{\circ}$ (b) for hilly terrain, i.e., $0^{\circ}$ to $50^{\circ}$ and $290^{\circ}$ to $360^{\circ}$.

As shown in many previous studies, the wind characteristics in Hong Kong are subject to distinct seasonal variability $[22,74,75]$. On the other hand, atmospheric stability also plays an essential role in modulating the wind veer characteristics since it governs the vertical distribution of momentum and other thermodynamic components in the atmospheric boundary layer $[12,29,31,34,76]$. On this account, it is necessary to investigate the seasonal variability of wind veer characteristics with a consideration of the change in atmospheric stability.

Given the lack of temperature measurements, the atmospheric stability is determined based on the simplified method proposed by Basu $[77,78]$, in which the Obukhov length $(L)$ can be calculated using only the wind speed data:

(1) R is calculated based on wind speed measured at three different heights (e.g., in this study, $\left.z_{1}=23.8 \mathrm{~m}, z_{2}=28.8 \mathrm{~m}, z_{3}=33.9 \mathrm{~m}\right)$ : 


$$
\mathrm{R}=\frac{\Delta U_{31}}{\Delta U_{21}}=\frac{\ln \left(\frac{z_{3}}{z_{1}}\right)-\psi_{M}\left(\frac{z_{3}}{L}\right)+\psi_{M}\left(\frac{z_{1}}{L}\right)}{\ln \left(\frac{z_{2}}{z_{1}}\right)-\psi_{M}\left(\frac{z_{2}}{L}\right)+\psi_{M}\left(\frac{z_{1}}{L}\right)}
$$

where $\psi_{M}$ is the stability correction term, $\Delta U_{31}$ is the wind speed difference measured at heights $z_{3}$ and $z_{1}$ and $\Delta U_{21}$ is the wind speed difference measured at heights $z_{2}$ and $z_{1}$. It should be noted that the relatively lower measurement heights are used mainly because the adopted method for determining atmospheric stability is deeply rooted in Monin-Obukhov similarity theory (MOST; [79]). Therefore, all the measurement heights used in this relation should be within the surface layer (i.e., constant flux layer), where MOST is valid [77,78].

(2) $\mathrm{R}_{N}$ is calculated according to the given heights, assuming $z_{3}>z_{2}>z_{1}$ :

$$
\mathrm{R}_{N}=\frac{\ln \left(\frac{z_{3}}{z_{1}}\right)}{\ln \left(\frac{z_{2}}{z_{1}}\right)}
$$

(3) The Obukhov length (L) is determined using the empirical $\psi_{M}$ functions [80,81]. If $R>R_{N}$, Equation (1) is used in conjunction with Equation (3). Conversely, if $R<R_{N}$, then Equation (3) is replaced with Equation (4).

$$
\begin{gathered}
\psi_{M}=2 \ln \left(\frac{1+x}{2}\right)+\ln \left(\frac{1+x^{2}}{2}\right)-2 \tan ^{-1} x+\frac{\pi}{2} \\
\psi_{M}=-\frac{5 z}{L}
\end{gathered}
$$

in which $x=\left(1-\frac{16 z}{L}\right)^{1 / 4}$. Consequently, the classification of atmospheric stability in this study is tabulated in Table 1 .

Table 1. Classification of atmospheric stability in this study.

\begin{tabular}{cccc}
\hline Category & Description & $\boldsymbol{L}(\mathbf{m})$ & $\boldsymbol{R}$ \\
\hline A & Stable & $10 \leq L \leq 200$ & $1.9023 \leq R \leq 1.9885$ \\
B & Neutral & $|L| \geq 200$ & $1.8127 \leq R \leq 1.9023$ \\
C & Unstable & $-200 \leq L \leq-50$ & $1.8053 \leq R \leq 1.8127$ \\
\hline
\end{tabular}

As can be seen in Figure 7, the wind veer characteristics behave in response to the change in both seasonality and atmospheric stability. Seasonal variability is apparent with respect to the shape and magnitude of wind veer angle. Specifically, larger wind veer angles are mostly observed during winter (i.e., December, January and February) and spring (i.e., March, April and May) months, with a maximum value of about $5.5^{\circ}$, whereas the wind veer during autumn (i.e., September, October and November) is much less significant, indicating a wind veer angle smaller than $0.8^{\circ}$. The larger wind veer angles during spring and winter can be mainly attributed to the more frequent occurrence of a low-level jet during these months [67]. Peña et al. [12] and Brown et al. [29] both stated that the presence of low-level jets is advantageous for yielding more significant wind veer since the wind near the low-level maximum can be much larger than the geostrophic wind. Moreover, the height where the wind veer profile starts to increase is also found to be a function of seasonal variation, in which the value associated with winter and spring months is about $100 \mathrm{~m}$, whereas that for summer (i.e., June, July and August) and autumn is about $80 \mathrm{~m}$. On the other hand, the dependence of wind veer profile on atmospheric stability is also examined, which is most pronounced during spring and winter. Typically, a larger wind veer angle is often linked to neutral stratification conditions, whereas the smallest wind veer angle is associated with unstable stratification conditions. The effect of atmospheric 
stability on the wind veer profile can also be found during summer and autumn, but not to such a significant extent.
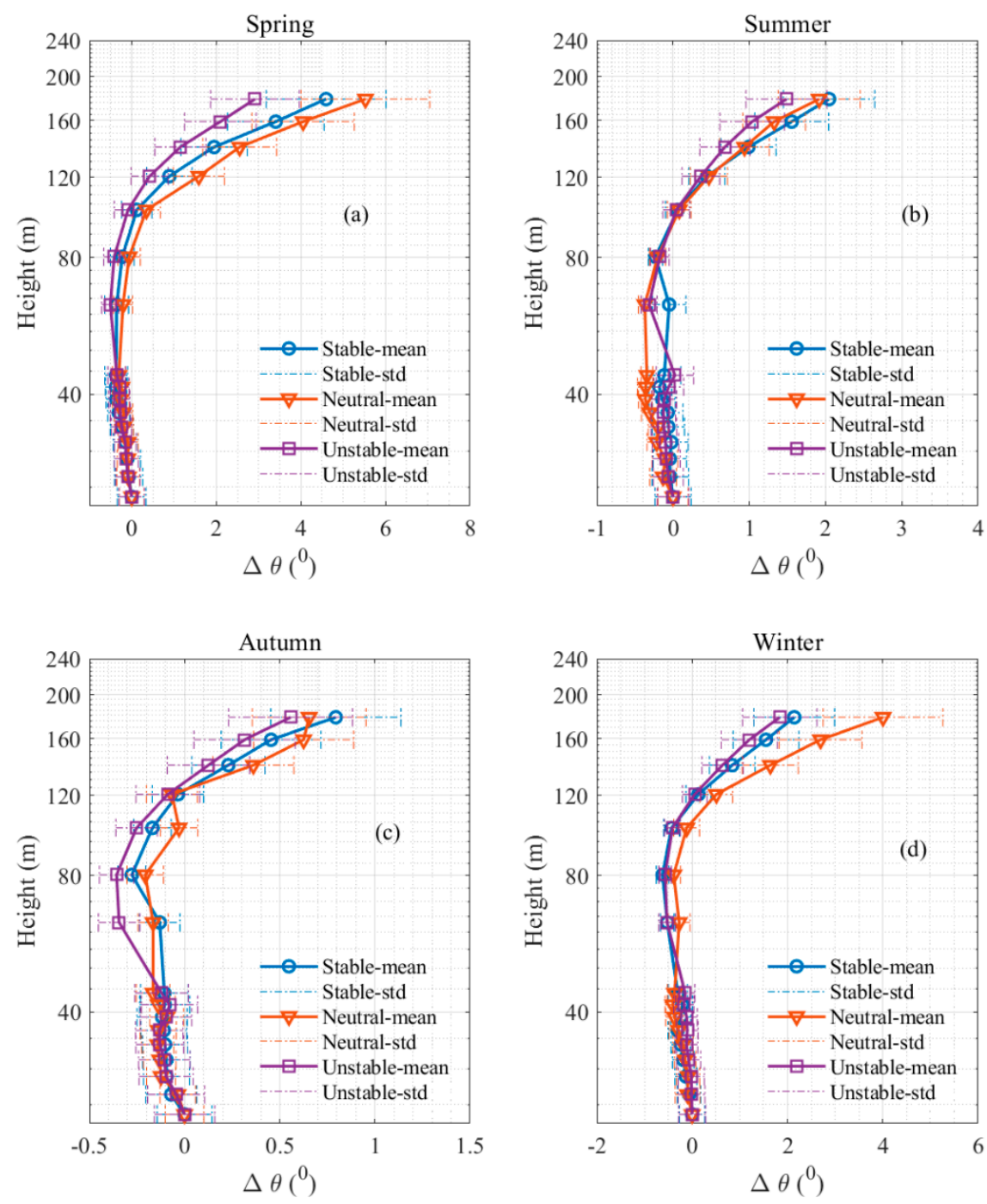

Figure 7. Composite wind veer profiles as a function of seasonality. (a) spring (b) summer (c) autumn (d) winter.

\section{Summary and Conclusions}

A proper understanding of marine wind characteristics is important, which provides great implications across a wide range of engineering applications, in particular offshore wind turbine design and wind power output. However, the majority of the existing literature has been focused on offshore wind speed and turbulence characteristics, whereas the knowledge of wind veer is much less understood and discussed. This study investigates the marine wind veer characteristics based on extensive Lidar observations at an offshore platform in Hong Kong. The major conclusions in this study can be summarized as follows:

- The occurrence of wind veer in the marine wind field was well observed, which can be affected by the change of upstream terrain conditions. In general, the wind veer profiles tend to exhibit a two-fold structure, in which the wind veer angle in the lower observation altitudes is likely to remain unchanged or slightly decrease, whereas at higher observation altitudes, the wind veer angle usually increases monotonically with height. From a comparative analysis point of view, the wind veer angles for hilly terrain conditions are much larger than those for open-sea terrain. 
- The maximum wind veer angle tends to exhibit a reverse correlation with mean wind speed, i.e., the larger the mean wind speed, the smaller the veering angle. With an increase in mean wind speed, the value decreases from $2.47^{\circ}$ to $0.59^{\circ}$ for open-sea terrain, and from $7.45^{\circ}$ to $1.92^{\circ}$ for hilly terrain.

- Seasonal variability of the wind veer profile is apparent, in which winter and spring often possess larger values of wind veer angle, whereas autumn usually possesses the smallest value. On the other hand, the height at which the wind veer profile starts to increase with height is also found to be a function of seasonality.

- The dependence of wind veer on atmospheric stability was examined, which is most pronounced during spring and winter. Typically, larger wind veer angles can be found under neutral stratification conditions.

It, however, should be noted that the results given in the present paper are based on Lidar observations made at an offshore platform in Hong Kong, which could be more or less site specific. The inclusion of more extensive observations to a larger spatial extent is recommended in a view to provide a more general understanding of wind veer characteristics in the marine environment.

Author Contributions: Z.S.: Writing-original draft; Writing-review and editing; Investigation; Q.L.: Funding acquisition; Writing - review and editing; Supervision; P.W.C.: Resources; Data curation, Funding acquisition; Y.H.: Data curation; Methodology. All authors have read and agreed to the published version of the manuscript.

Funding: The work described in this paper was fully supported by grants from the Fundamental Research Program of Shenzhen Municipality (Project No.: JCYJ20170817111535167), a grant from the National Natural Science Foundation of China (Project No.: 51978593) and a grant from the Research Grants Council of Hong Kong Special Administrative Region, China (Project No.: CityU 11204020).

Acknowledgments: The authors would like to thank Hong Kong Observatory for providing the measurement data analyzed in this paper.

Conflicts of Interest: The authors declare no competing interest.

\section{References}

1. International Energy Association. Renewables 2019. Available online: https://www.iea.org/reports/ renewables-2019 (accessed on 3 October 2020).

2. REN21. Renewables 2020, Global Status Report. Available online: https:/www.ren21.net/wp-content/ uploads/2019/05/gsr_2020_full_report_en.pdf (accessed on 25 September 2020).

3. Esteban, M.D.; Diez, J.J.; López, J.S.; Negro, V. Why offshore wind energy? Renew. Energy 2011, 36, 444-450. [CrossRef]

4. GWEC, Global Wind Energy Council. Global Wind Report: Annual Market Update 2019. Available online: https://gwec.net/global-wind-report-2019/ (accessed on 1 October 2020).

5. Shu, Z.R.; Li, Q.S.; Chan, P.W. Investigation of offshore wind energy potential in Hong Kong based on Weibull distribution function. Appl. Energy 2015, 156, 362-373. [CrossRef]

6. Kikuchi, Y.; Fukushima, M.; Ishihara, T. Assessment of a coastal offshore wind climate by means of mesoscale model simulations considering high-resolution land use and sea surface temperature data sets. Atmosphere 2020, 11, 379. [CrossRef]

7. Goit, J.P.; Yamaguchi, A.; Ishihara, T. Measurement and Prediction of Wind Fields at an Offshore Site by Scanning Doppler LiDAR and WRF. Atmosphere 2020, 11, 442. [CrossRef]

8. Fairall, C.W.; Bradley, E.F.; Rogers, D.P.; Edson, J.B.; Young, G.S. Bulk parameterization of air-sea fluxes for tropical ocean-global atmosphere coupled-ocean atmosphere response experiment. J. Geophys. Res. Ocean. 1996, 101, 3747-3764. [CrossRef]

9. Svensson, N.; Arnqvist, J.; Bergström, H.; Rutgersson, A.; Sahlée, E. Measurements and Modelling of Offshore Wind Profiles in a Semi-Enclosed Sea. Atmosphere 2019, 10, 194. [CrossRef]

10. Smith, D.A.; Harris, M.; Coffey, A.S.; Mikkelsen, T.; Jørgensen, H.E.; Mann, J.; Danielian, R. Wind lidar evaluation at the Danish wind test site in Høvsøre. Wind Energy Int. J. Prog. Appl. Wind Power Convers. Technol. 2006, 9, 87-93. [CrossRef] 
11. Peña, A.; Hasager, C.B.; Gryning, S.E.; Courtney, M.; Antoniou, I.; Mikkelsen, T. Offshore wind profiling using light detection and ranging measurements. Wind Energy Int. J. Prog. Appl. Wind Power Convers. Technol. 2009, 12, 105-124. [CrossRef]

12. Peña, A.; Floors, R.; Gryning, S.E. The Høvsøre tall wind-profile experiment: A description of wind profile observations in the atmospheric boundary layer. Bound.-Layer Meteorol. 2014, 150, 69-89. [CrossRef]

13. Kindler, D.; Oldroyd, A.; Macaskill, A.; Finch, D. An eight month test campaign of the Qinetiq ZephIR system: Preliminary results. Meteorol. Z. 2007, 16, 479-489. [CrossRef]

14. Pichugina, Y.L.; Banta, R.M.; Brewer, W.A.; Sandberg, S.P.; Hardesty, R.M. Doppler lidar-based wind-profile measurement system for offshore wind-energy and other marine boundary layer applications. J. Appl. Meteorol. Clim. 2012, 51, 327-349. [CrossRef]

15. Kalverla, P.C.; Steeneveld, G.J.; Ronda, R.J.; Holtslag, A.A. An observational climatology of anomalous wind events at offshore meteomast IJmuiden (North Sea). J. Wind Eng. Ind. Aerodyn. 2017, 165, 86-99. [CrossRef]

16. He, Y.C.; Chan, P.W.; Li, Q.S. Observations of vertical wind profiles of tropical cyclones at coastal areas. J. Wind Eng. Ind. Aerodyn. 2016, 152, 1-14. [CrossRef]

17. Morgan, E.C.; Lackner, M.; Vogel, R.M.; Baise, L.G. Probability distributions for offshore wind speeds. Energy Convers. Manag. 2011, 52, 15-26. [CrossRef]

18. Shu, Z.R.; Li, Q.S.; He, Y.C.; Chan, P.W. Observations of offshore wind characteristics by Doppler-LiDAR for wind energy applications. Appl. Energy 2016, 169, 150-163. [CrossRef]

19. Gryning, S.E.; Floors, R.; Peña, A.; Batchvarova, E.; Brümmer, B. Weibull wind-speed distribution parameters derived from a combination of wind-lidar and tall-mast measurements over land, coastal and marine sites. Bound.-Layer Meteorol. 2016, 159, 329-348. [CrossRef]

20. Launiainen, J.; Laurila, T. Marine wind characteristics in the northern Baltic Sea. Finn. Mar. Res. 1984, $250,52-86$.

21. Chien, H.; Cheng, H.Y.; Yang, K.H.; Tsai, Y.H.; Chang, W.T. Diurnal and semidiurnal variability of coastal wind over Taiwanese waters. Wind Energy 2015, 18, 1353-1370. [CrossRef]

22. Shu, Z.R.; Li, Q.S.; Chan, P.W.; He, Y.C. Seasonal and diurnal variation of marine wind characteristics based on lidar measurements. Meteorol. Appl. 2020, 27, e1918. [CrossRef]

23. Lange, B.; Larsen, S.; Højstrup, J.; Barthelmie, R. Importance of thermal effects and sea surface roughness for offshore wind resource assessment. J. Wind Eng. Ind. Aerodyn. 2004, 92, 959-988. [CrossRef]

24. He, Y.C.; Fu, J.Y.; Shu, Z.R.; Chan, P.W.; Wu, J.R.; Li, Q.S. A comparison of micrometeorological methods for marine roughness estimation at a coastal area. J. Wind Eng. Ind. Aerodyn. 2019, 195, 104010. [CrossRef]

25. He, Y.C.; Shu, Z.R.; Li, Q.S.; Chan, P.W. Standardization of marine surface wind speeds at coastal islands. Ocean Eng. 2020, 213, 107652. [CrossRef]

26. Türk, M.; Emeis, S. The dependence of offshore turbulence intensity on wind speed. J. Wind Eng. Ind. Aerodyn. 2010, 98, 466-471. [CrossRef]

27. Mendenhall, B.R. A Statistical Study of Frictional Wind Veering in the Planetary Boundary Layer; Department of Atmospheric Science, Colorado State University: Fort Collins, CO, USA, 1967.

28. Yeo, D.H.; Simiu, E. Database-Assisted Design for Wind: Veering Effects on High-Rise Structures; No. Technical Note (NIST TN)-1672; NIST: Gaithersburg, MD, USA, 2010.

29. Brown, A.R.; Beljaars AC, M.; Hersbach, H.; Hollingsworth, A.; Miller, M.; Vasiljevic, D. Wind turning across the marine atmospheric boundary layer. Q. J. R. Meteorol. Soc. 2005, 131, 1233-1250. [CrossRef]

30. Yeo, D. Practical estimation of veering effects on high-rise structures: A database-assisted design approach. Wind Struct. 2012, 15, 355. [CrossRef]

31. Peña, A.; Gryning, S.E.; Floors, R. The turning of the wind in the atmospheric boundary layer. J. Phys. Conf. Ser. 2014, 524, 012118. [CrossRef]

32. Crawford, K.C.; Hudson, H.R. The diurnal wind variation in the lowest $1500 \mathrm{ft}$ in central Oklahoma. June 1966-May 1967. J. Appl. Meteorol. 1973, 12, 127-132. [CrossRef]

33. Peña, A.; Gryning, S.E.; Hahmann, A.N. Observations of the atmospheric boundary layer height under marine upstream flow conditions at a coastal site. J. Geophys. Res. Atmos. 2013, 118, 1924-1940. [CrossRef]

34. Peña, A.; Gryning, S.E.; Floors, R.R. Lidar observations of marine boundary-layer winds and heights: A preliminary study. Meteorol. Z. 2015, 24, 581-589. [CrossRef]

35. He, Y.C.; Chan, P.W.; Li, Q.S. Wind profiles of tropical cyclones as observed by Doppler wind profiler and anemometer. Wind Struct. 2013, 17, 419-433. [CrossRef] 
36. Liu, Z.; Zheng, C.; Wu, Y.; Song, Y. Investigation on characteristics of thousand-meter height wind profiles at non-tropical cyclone prone areas based on field measurement. Build. Environ. 2018, 130, 62-73. [CrossRef]

37. Shu, Z.R.; Li, Q.S.; He, Y.C.; Chan, P.W. Observational study of veering wind by Doppler wind profiler and surface weather station. J. Wind Eng. Ind. Aerodyn. 2018, 178, 18-25. [CrossRef]

38. Lindvall, J.; Svensson, G. Wind turning in the atmospheric boundary layer over land. Q. J. R. Meteorol. Soc. 2019, 145, 3074-3088. [CrossRef]

39. Liu, Z.; Zheng, C.; Wu, Y.; Flay, R.G.; Zhang, K. Investigation on the effects of twisted wind flow on the wind loads on a square section megatall building. J. Wind Eng. Ind. Aerodyn. 2019, 191, 127-142. [CrossRef]

40. Tse, K.T.; Weerasuriya, A.U.; Kwok, K.C. Simulation of twisted wind flows in a boundary layer wind tunnel for pedestrian-level wind tunnel tests. J. Wind Eng. Ind. Aerodyn. 2016, 159, 99-109. [CrossRef]

41. Tse, K.T.; Weerasuriya, A.U.; Zhang, X.; Li, S.W.; Kwok, K.C. Effects of twisted wind flows on wind conditions in passages between buildings. J. Wind Eng. Ind. Aerodyn. 2017, 167, 87-100. [CrossRef]

42. Tse, K.T.; Weerasuriya, A.U.; Zhang, X.; Li, S.; Kwok, K.C. Pedestrian-level wind environment around isolated buildings under the influence of twisted wind flows. J. Wind Eng. Ind. Aerodyn. 2017, 162, 12-23. [CrossRef]

43. Flay, R.G. A twisted flow wind tunnel for testing yacht sails. J. Wind Eng. Ind. Aerodyn. 1996, 63, 171-182. [CrossRef]

44. Flay, R.G.J.; Locke, N.J.; Mallinson, G.D. Model tests of twisted flow wind tunnel designs for testing yacht sails. J. Wind Eng. Ind. Aerodyn. 1996, 63, 155-169. [CrossRef]

45. Brugger, P.; Fuertes, F.C.; Vahidzadeh, M.; Markfort, C.D.; Porté-Agel, F. Characterization of wind turbine wakes with Nacelle-Mounted Doppler LiDARs and model validation in the presence of wind veer. Remote Sens. 2019, 11, 2247. [CrossRef]

46. Churchfield, M.J.; Sirnivas, S. On the effects of wind turbine wake skew caused by wind veer. In Proceedings of the 2018 Wind Energy Symposium, Perth, Australia, 20-22 November 2018; p. 0755.

47. Englberger, A.; Lundquist, J.K. How does inflow veer affect the veer of a wind-turbine wake? J. Phys. Conf. Ser. 2020, 1452, 012068. [CrossRef]

48. Choukulkar, A.; Pichugina, Y.; Clack, C.T.M.; Calhoun, R.; Banta, R.; Brewer, A.; Hardesty, M. A new formulation for rotor equivalent wind speed for wind resource assessment and wind power forecasting. Wind Energy 2016, 19, 1439-1452. [CrossRef]

49. Bardal, L.M.; Sætran, L.R.; Wangsness, E. Performance test of a 3MW wind turbine-effects of shear and turbulence. Energy Procedia 2015, 80, 83-91. [CrossRef]

50. Eriksson, O.; Breton, S.P.; Nilsson, K.; Ivanell, S. Impact of wind veer and the Coriolis force for an idealized farm to farm interaction case. Appl. Sci. 2019, 9, 922. [CrossRef]

51. Murphy, P.; Lundquist, J.K.; Fleming, P. How wind speed shear and directional veer affect the power production of a megawatt-scale operational wind turbine. Wind Energy Sci. Discuss. 2019, 2019, 1-46.

52. Li, G. Feasibility of large scale offshore wind power for Hong Kong-A preliminary study. Renew. Energy 2000, 21, 387-402. [CrossRef]

53. Gao, X.; Yang, H.; Lu, L. Study on offshore wind power potential and wind farm optimization in Hong Kong. Appl. Energy 2014, 130, 519-531. [CrossRef]

54. Gao, X.; Yang, H.; Lu, L. Investigation into the optimal wind turbine layout patterns for a Hong Kong offshore wind farm. Energy 2014, 73, 430-442. [CrossRef]

55. Gao, X.; Yang, H.; Lin, L.; Koo, P. Wind turbine layout optimization using multi-population genetic algorithm and a case study in Hong Kong offshore. J. Wind Eng. Ind. Aerodyn. 2015, 139, 89-99. [CrossRef]

56. Shu, Z.R.; Li, Q.S.; Chan, P.W. Statistical analysis of wind characteristics and wind energy potential in Hong Kong. Energy Convers. Manag. 2015, 101, 644-657. [CrossRef]

57. Dai, L.D.; Xin, J.Y.; Zuo, H.C.; Ma, Y.X.; Zhang, L.; Wu, X.R.; Ma, Y.J.; Jia, D.J.; Wu, F.K. Multilevel Validation of Doppler Wind Lidar by the $325 \mathrm{~m}$ Meteorological Tower in the Planetary Boundary Layer of Beijing. Atmosphere 2020, 11, 1051. [CrossRef]

58. Canepa, F.; Burlando, M.; Solari, G. Vertical profile characteristics of thunderstorm outflows. J. Wind Eng. Ind. Aerodyn. 2020, 206, 104332. [CrossRef]

59. Ricci, A.; Burlando, M.; Repetto, M.P.; Blocken, B. Simulation of urban boundary and canopy layer flows in port areas induced by different marine boundary layer inflow conditions. Sci. Total Environ. 2019, 670, 876-892. [CrossRef] [PubMed] 
60. Zhang, S.; Solari, G.; Yang, Q.; Repetto, M.P. Extreme wind speed distribution in a mixed wind climate. J. Wind Eng. Ind. Aerodyn. 2018, 176, 239-253. [CrossRef]

61. Zhang, S.; Solari, G.; De Gaetano, P.; Burlando, M.; Repetto, M.P. A refined analysis of thunderstorm outflow characteristics relevant to the wind loading of structures. Probabilistic Eng. Mech. 2018, 54, 9-24. [CrossRef]

62. Hofsäß, M.; Clifton, A.; Cheng, P.W. Reducing the uncertainty of Lidar measurements in complex terrain using a linear model approach. Remote Sens. 2018, 10, 1465. [CrossRef]

63. Wagner, R.; Mikkelsen, T.; Courtney, M. Investigation of turbulence measurements with a continuous wave, conically scanning LiDAR. Risoe DTU Rosk. 2009, 1682, 1-22.

64. Powell, M.D.; Vickery, P.J.; Reinhold, T.A. Reduced drag coefficient for high wind speeds in tropical cyclones. Nature 2003, 422, 279-283. [CrossRef]

65. Tamura, Y.; Iwatani, Y.; Hibi, K.; Suda, K.; Nakamura, O.; Maruyama, T.; Ishibashi, R. Profiles of mean wind speeds and vertical turbulence intensities measured at seashore and two inland sites using Doppler sodars. J. Wind Eng. Ind. Aerodyn. 2007, 95, 411-427. [CrossRef]

66. Shu, Z.R.; Li, Q.S.; He, Y.C.; Chan, P.W. Vertical wind profiles for typhoon, monsoon and thunderstorm winds. J. Wind Eng. Ind. Aerodyn. 2017, 168, 190-199. [CrossRef]

67. Shu, Z.R.; Li, Q.S.; He, Y.C.; Chan, P.W. Investigation of low-level jet characteristics based on wind profiler observations. J. Wind Eng. Ind. Aerodyn. 2018, 174, 369-381. [CrossRef]

68. Rudeva, I.; Gulev, S.K. Composite analysis of North Atlantic extratropical cyclones in NCEP-NCAR reanalysis data. Mon. Weather Rev. 2011, 139, 1419-1446. [CrossRef]

69. Bauer, M.; Del Genio, A.D. Composite analysis of winter cyclones in a GCM: Influence on climatological humidity. J. Clim. 2006, 19, 1652-1672. [CrossRef]

70. Evans, J.L.; Guishard, M.P. Atlantic subtropical storms. Part I Diagn. Criteria Compos. Anal. Mon. Weather Rev. 2009, 137, 2065-2080.

71. Johnson, R.H.; Nicholls, M.E. A composite analysis of the boundary layer accompanying a tropical squall line. Mon. Weather Rev. 1983, 111, 308-319. [CrossRef]

72. Tsvieli, Y.; Zangvil, A. Synoptic climatological analysis of 'wet'and 'dry'Red Sea troughs over Israel. Int. J. Clim. J. R. Meteorol. Soc. 2005, 25, 1997-2015.

73. Limpasuvan, V.; Hartmann, D.L. Wave-maintained annular modes of climate variability. J. Clim. 2000, 13, 4414-4429. [CrossRef]

74. Yan, Y.Y. Surface wind characteristics and variability in Hong Kong. Weather 2007, 62, 312-316. [CrossRef]

75. Lu, X.; Chow, K.C.; Yao, T.; Fung, J.C.; Lau, A.K. Seasonal variation of the land-sea breeze circulation in the pearl river delta region. J. Geophys. Res. Atmos. 2009, 114, D17. [CrossRef]

76. Archer, C.L.; Colle, B.A.; Veron, D.L.; Veron, F.; Sienkiewicz, M.J. On the predominance of unstable atmospheric conditions in the marine boundary layer offshore of the US northeastern coast. J. Geophys. Res. Atmos. 2016, 121, 8869-8885. [CrossRef]

77. Basu, S. A simple recipe for estimating atmospheric stability solely based on surface-layer wind speed profile. Wind Energy 2018, 21, 937-941. [CrossRef]

78. Basu, S. Hybrid profile-gradient approaches for the estimation of surface fluxes. Bound.-Layer Meteorol. 2019, 170, 29-44. [CrossRef] [PubMed]

79. Monin, A.S.; Obukhov, A.M. Basic laws of turbulent mixing in the atmosphere near the ground. Tr. Geofiz Inst. Akad. Nauk SSSR 1954, 24, 163-187.

80. Dyer, A. A review of flux-profile relationships. Bound.-Layer Meteorol. 1974, 7, 363-372. [CrossRef]

81. Dyer, A.J.; Hicks, B.B. Flux-gradient relationships in the constant flux layer. Q. J. R. Meteorol. Soc. 1970, 96, 715-721. [CrossRef]

Publisher's Note: MDPI stays neutral with regard to jurisdictional claims in published maps and institutional affiliations. 